\title{
Note
}

\section{Acceleration of Acid-Catalyzed Hydrolysis in a Biphasic System by Sodium Tetracyanocyclopentadienides}

\author{
Takeo Sakai,* Mariko Bito, Makoto Itakura, Honami Sato, and Yuji Mori* \\ Faculty of Pharmacy, Meijo University; 150 Yagotoyama, Tempaku-ku, Nagoya 468-8503, Japan. \\ Received February 16, 2016; accepted March 15, 2016
}

\begin{abstract}
The hydrolysis of tert-butyldimethylsilyl L-menthyl ether (3) in a $\mathrm{CH}_{2} \mathrm{Cl}_{2}-1 \mathrm{M} \mathrm{HCl}$ biphasic solvent system was accelerated by the addition of sodium tetracyanocyclopentadienides 1 . Particularly, the reaction rate was enhanced using sodium salt 1a-c with a lipophilic substituent on the cyclopentadienide ring. From the results obtained by a triphasic experiment, hydrolysis proceeds via the formation of hydronium ion 2 in the aqueous phase by ion exchange, followed by the transfer of 2 to the $\mathrm{CH}_{2} \mathrm{Cl}_{2}$ phase.
\end{abstract}

Key words phase-transfer reaction; hydrolysis; tetracyanocyclopentadienide; acid-catalyzed reaction

Phase-transfer reactions have garnered increasing attention in organic chemistry because of their mild, sustainable conditions. ${ }^{1)}$ Phase-transfer catalysts (PTCs) enhance the reactivity of anionic reagents by forming a lipophilic ion pair, mediating a reaction in the organic phase or at the interface between two phases. Enantioselective phase-transfer reactions catalyzed by chiral quaternary ammonium salts are one of the representative methods for synthesizing optically active molecules. ${ }^{2,3)}$ Anionic PTCs have also been developed for reactions where lipophilic anions enhance the solubility of the reactive cationic species, thereby promoting the reactions. Kobayashi et al. have reported the first anionic phase-transfer reaction using tetrakis(3,5-bis(trifluoromethyl)phenyl)borate (TFPB) anion. ${ }^{4-6)}$ Recently, asymmetric anionic phase-transfer reactions ${ }^{7,8)}$ have been reported using chiral phosphates with an aziridinium cation $^{9)}$ and $N$-haloammonium cations. ${ }^{10-18)}$ However, a limited number of studies have been reported about anionic PTCs. Weakly basic anions are candidates for anionic PTCs because they barely undergo protonation or react with other cationic species. Tetracyanocyclopentadienides $\left(\mathrm{C}_{5} \mathrm{R}(\mathrm{CN})_{4}{ }^{-}\right)^{19-21)}$ are weakly basic anions; their conjugate acids exhibit very small $\mathrm{p} K_{\mathrm{a}}$ values as superacids, e.g., perchloric acid. ${ }^{223)}$ Recently, we have efficiently synthesized<smiles></smiles>

$1 \mathrm{a}$<smiles></smiles>

1d<smiles>N#Cc1c(C#N)c(CCOc2ccccc2)c(C#N)c([N+]#N)c1C#N</smiles>

$1 b$

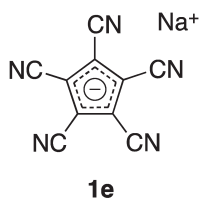

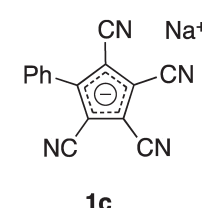

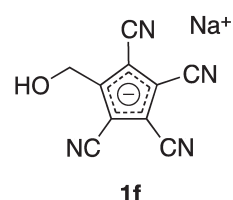

Fig. 1. Sodium Tetracyanocyclopentadienides $\mathrm{Na}_{2}\left[\mathrm{C}_{5} \mathrm{R}(\mathrm{CN})_{4}\right] \mathbf{1 a}-\mathbf{f}$ various $\mathrm{Na}\left[\mathrm{C}_{5} \mathrm{R}(\mathrm{CN})_{4}\right]$ salts $\mathbf{1 a}-\mathbf{f}$ from tetracyanothiophene and sulfones and achieved direct functionalization at a substitution position R (Fig. 1). ${ }^{24)}$ During our previous study, we noticed that salts $\mathbf{1 a}-\mathbf{f}$ are miscible in polar organic solvents (MeCN, tetrahydrofuran (THF), EtOAc) and can be extracted with organic solvents by partitioning between EtOAc and $\mathrm{H}_{2} \mathrm{O}$, despite the absence of large hydrophobic functional groups. Such unique lipophilic behavior exhibited by the $\mathrm{C}_{5} \mathrm{R}(\mathrm{CN})_{4}$ salts $\mathbf{1 a}-\mathbf{f}$ stimulated us to explore their catalytic activities in a biphasic solvent system.

We envisaged that $\mathrm{Na}\left[\mathrm{C}_{5} \mathrm{R}(\mathrm{CN})_{4}\right] \mathbf{1}$ could serve as a carrier of hydronium cations in the organic phase of the $\mathrm{CH}_{2} \mathrm{Cl}_{2}-$ $\mathrm{H}_{2} \mathrm{O}$ biphasic system (Fig. 2). In the aqueous phase of the biphasic system, $\mathrm{HCl}$ dissociates, forming a hydronium cation $\left(\mathrm{H}_{3} \mathrm{O}^{+}\right)$and chloride anion $\left(\mathrm{Cl}^{-}\right)$. The addition of $\mathbf{1}$ to the aqueous phase forms hydronium salt $\mathrm{H}_{3} \mathrm{O}^{+}\left[\mathrm{C}_{5} \mathrm{R}(\mathrm{CN})_{4}\right]^{-} \boldsymbol{2}$ by ion exchange, which is a hydronium ion that is "masked" by the lipophilic tetracyanocyclopentadienide group; it can be extracted into the $\mathrm{CH}_{2} \mathrm{Cl}_{2}$ phase. This working hypothesis

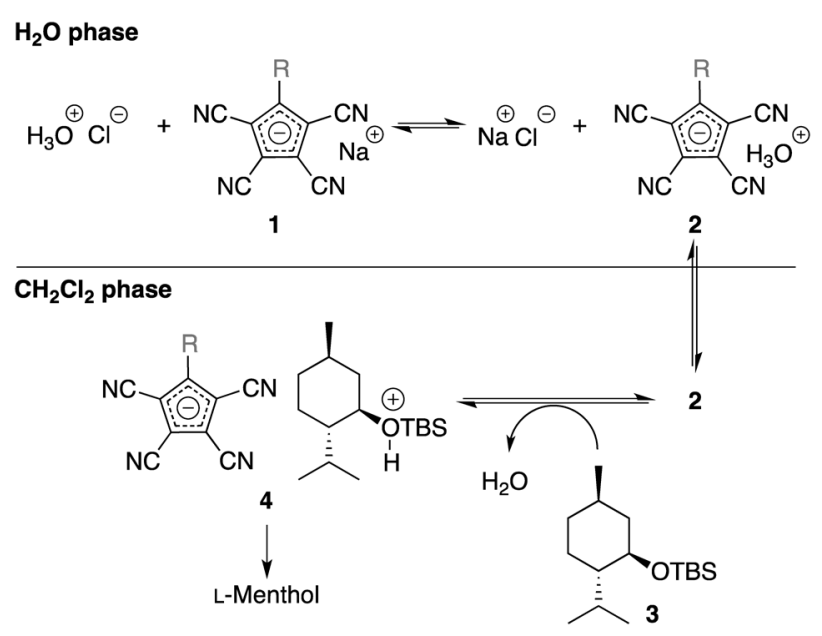

Fig. 2. Role of $\mathrm{C}_{5} \mathrm{R}(\mathrm{CN})_{4}$ Anion in the $\mathrm{H}_{2} \mathrm{O}-\mathrm{CH}_{2} \mathrm{Cl}_{2}$ Biphasic System

*To whom correspondence should be addressed. e-mail: sakait@meijo-u.ac.jp; mori@meijo-u.ac.jp 
Table 1. Effect of Catalyst and Aqueous Phase Acidity on the Hydrolysis of TBS Ether 3

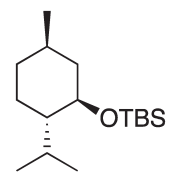

3

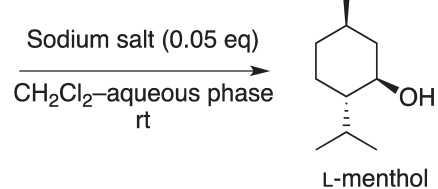

L-menthol

\begin{tabular}{|c|c|c|c|c|}
\hline Entry & Sodium salt & Aqueous phase & Time (h) & L-Menthol $(\%)$ \\
\hline 1 & $\mathrm{Na}\left[\mathrm{C}_{5}\left(\mathrm{CO}_{2} \mathrm{Menthyl}\right)(\mathrm{CN})_{4}\right] \mathbf{1 a}$ & $\mathrm{H}_{2} \mathrm{O}$ & 24 & 0 \\
\hline 2 & $\mathrm{Na}\left[\mathrm{C}_{5}\left(\mathrm{CO}_{2} \mathrm{Menthyl}\right)(\mathrm{CN})_{4}\right] \mathbf{1 a}$ & pH 4 buffer & 24 & 0 \\
\hline 3 & $\mathrm{Na}\left[\mathrm{C}_{5}\left(\mathrm{CO}_{2} \mathrm{Menthyl}\right)(\mathrm{CN})_{4}\right] \mathbf{1 a}$ & $0.03 \mathrm{M} \mathrm{HCl}$ & 20 & 89 \\
\hline 4 & $\mathrm{Na}\left[\mathrm{C}_{5}\left(\mathrm{CO}_{2} \mathrm{Menthyl}\right)(\mathrm{CN})_{4}\right] \mathbf{1 a}$ & $1.0 \mathrm{M} \mathrm{HCl}$ & 2 & 92 \\
\hline 5 & $\mathrm{NaClO}_{4}$ & $1.0 \mathrm{M} \mathrm{HCl}$ & 24 & 0 \\
\hline 6 & $\mathrm{NaBF}_{4}$ & $1.0 \mathrm{M} \mathrm{HCl}$ & 24 & 0 \\
\hline 7 & - & $1.0 \mathrm{M} \mathrm{HCl}$ & 24 & 0 \\
\hline
\end{tabular}

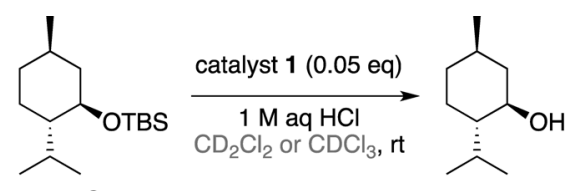

3

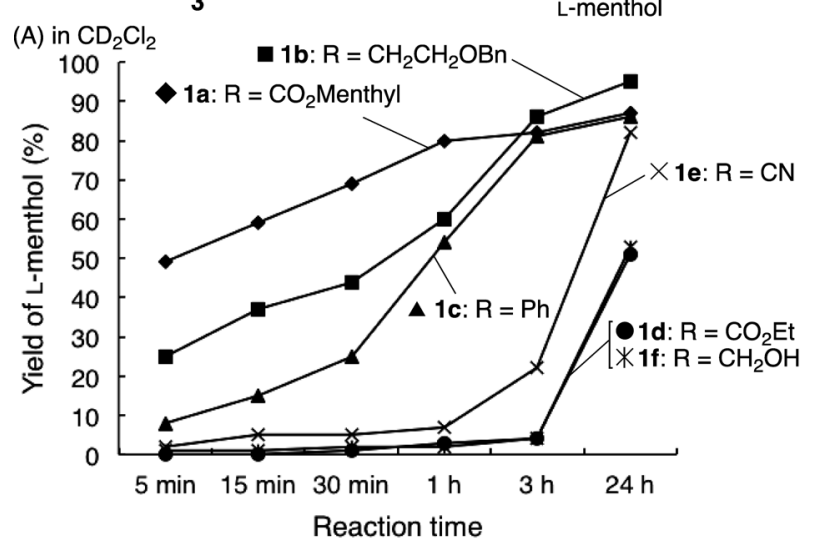

(B) in $\mathrm{CDCl}_{3}$

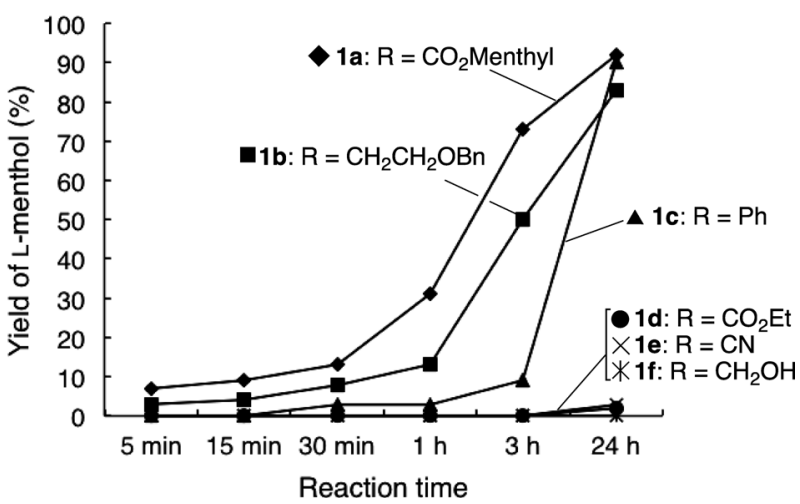

Fig. 3. NMR Study for the Reaction Rate for the Hydrolysis of 3 Catalyzed by 1 in (A) $1 \mathrm{M} \mathrm{HCl}-\mathrm{CD}_{2} \mathrm{Cl}_{2}$ or (B) $1 \mathrm{M} \mathrm{HCl}-\mathrm{CDCl}_{3}$

could be verified by investigating the hydrolysis of tert-butyldimethylsilyl (TBS) ether 3 to $\mathrm{L}-$ menthol in $\mathrm{CH}_{2} \mathrm{Cl}_{2}$ catalyzed by hydronium salt 2 .

The reaction rate for the hydrolysis of the TBS group was significantly affected by acid strength. We examined the effects of sodium salt 1a and acidity of the aqueous phase on the biphasic hydrolysis of $\mathbf{3}$ (Table 1). Hydrolysis did not proceed in water- $\mathrm{CH}_{2} \mathrm{Cl}_{2}$ and in a $\mathrm{pH} 4$ buffer solution- $\mathrm{CH}_{2} \mathrm{Cl}_{2}$ two-phase system (entries 1, 2, respectively). By using $0.03 \mathrm{~m}$
$\mathrm{HCl}$, the TBS group was eliminated, albeit very slowly (entry 3). Furthermore, with increasing acid concentration to $1.0 \mathrm{M}$, the hydrolysis rate increased, and desilylation was completed within $2 \mathrm{~h}$ (entry 4). By contrast, in the absence of 1a, the hydrolysis of 3 did not occur even when using $1.0 \mathrm{M} \mathrm{HCl}$ as the aqueous phase (entries 5-7). For comparison with representative superacid salts, $\mathrm{NaClO}_{4}$ and $\mathrm{NaBF}_{4}$ were examined. However, the desilylation was not induced because they could not be partitioned into the organic phase, attributed to the lack of lipophilicity (entries 5, 6, respectively).

Next, the effect of substitution of $\mathrm{C}_{5} \mathrm{R}(\mathrm{CN})_{4}$ salt $\mathbf{1}$ on the hydrolysis of 3 in a $1 \mathrm{M} \mathrm{HCl}$ and $\mathrm{CD}_{2} \mathrm{Cl}_{2}$ biphasic solvent system was investigated by ${ }^{1} \mathrm{H}-\mathrm{NMR}$ (Fig. 3(A)). Tetracyanocyclopentadienides $1 \mathbf{1 a}-\mathbf{c}$ with less polar substituents $\left(\mathrm{R}=\mathrm{CO}_{2}\right.$ menthyl $(\diamond), \mathrm{CH}_{2} \mathrm{CH}_{2} \mathrm{OBn}(\boldsymbol{\square})$, and $\mathrm{Ph}(\boldsymbol{\Delta})$, respectively) significantly accelerated hydrolysis, while those with polar substituents 1d-f $\left(\mathrm{R}=\mathrm{CO}_{2} \mathrm{Et}(\mathbf{O}), \mathrm{CN}(\times)\right.$, and $\mathrm{CH}_{2} \mathrm{OH}(*)$, respectively) resulted in slow reactions. These results suggest that more hydrophobic anions increase the amount of hydronium salt 2 dissolving in $\mathrm{CD}_{2} \mathrm{Cl}_{2}$. The hydrolysis of the TBS group in a $1 \mathrm{M} \mathrm{HCl}-\mathrm{CDCl}_{3}$ biphasic system was slower than that in $1 \mathrm{M}$ $\mathrm{HCl}-\mathrm{CD}_{2} \mathrm{Cl}_{2}$ (Fig. 3(B)). The decreased reaction rate in $\mathrm{CDCl}_{3}$ is attributed to a lower solubility of hydronium salt $\mathbf{2}$ in $\mathrm{CDCl}_{3}$ than in $\mathrm{CD}_{2} \mathrm{Cl}_{2}{ }^{25}$ ) The electron-withdrawing power of the substituent $\mathrm{R}$ of $\mathrm{C}_{5} \mathrm{R}(\mathrm{CN})_{4}$ anion did not affect the hydrolysis rate, as indicated by the moderate reaction rates of $\mathbf{1 d}-\mathbf{f}$.
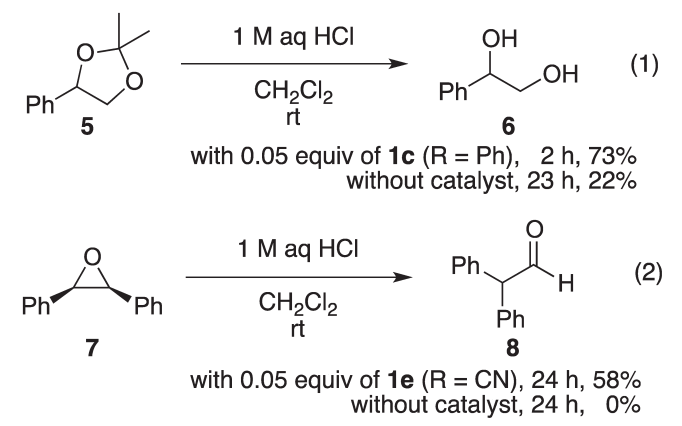

Other acid-catalyzed reactions by $\mathbf{1}$ were examined under the same biphasic system. A hydrolysis of acetal $\mathbf{5}$ provided diol 6 in only $22 \%$ yield after $23 \mathrm{~h}$ in the absence of catalyst 1. The addition of catalyst $1 \mathrm{c}$ to the biphasic system markedly enhanced the reaction rate, and diol 6 was obtained in $73 \%$ yield after $2 \mathrm{~h}$ (Eq. 1). As an example of a different type of reaction, we demonstrated an acid-catalyzed rearrangement of 
cis-stilbene oxide (7) to aldehyde $\mathbf{8}$, induced by addition of $\mathbf{1 e}$ (Eq. 2).

Next, we focused on the phase transfer ability of hydronium cation 2. Initially, we attempted to isolate the hydronium salt 2, an ion pair formed from $\mathrm{Na}\left[\mathrm{C}_{5} \mathrm{Ph}(\mathrm{CN})_{4}\right]$ (1c) and a hydronium cation, using a separating funnel. However, the $\mathrm{CH}_{2} \mathrm{Cl}_{2}$ extract of a solution of $1 \mathrm{c}$ in $1 \mathrm{M} \mathrm{HCl}$ did not afford enough tetracyanocyclopentadienide salt for detection by ${ }^{1} \mathrm{H}-\mathrm{NMR}$ and TLC. Then, another experiment was planned for determining the presence of $\mathbf{2}$ in $\mathrm{CH}_{2} \mathrm{Cl}_{2}$ phase using a right-angled U-tube, where two independent aqueous phases were separated by an organic phase (Fig. 4). A U-tube apparatus was equipped with a stir bar and two glass sticks, and another two stir bars were placed on the top of each glass stick. The Utube was filled with $\mathrm{CH}_{2} \mathrm{Cl}_{2}$ right up to the upper level of the glass sticks, and an aqueous phase was added over the $\mathrm{CH}_{2} \mathrm{Cl}_{2}$ phase in both arms (Phases A, B). After adding 1c to phase A, the whole system was stirred for the indicated time. ${ }^{26)}$ The percentages of the amount of the remaining 1c in phase A and the transferred amount to phase B were measured on the basis of the initial amount of $\mathbf{1 c}$.

In the case where both phases $\mathrm{A}$ and $\mathrm{B}$ were water, the transfer of the $\mathrm{C}_{5} \mathrm{Ph}(\mathrm{CN})_{4}$ anion from phase A to phase $\mathrm{B}$ was not observed regardless of the additive ether in the $\mathrm{CH}_{2} \mathrm{Cl}_{2}$ phase (Table 2, entries 1, 2, respectively). On the other hand, by changing the phases $\mathrm{A}$ and $\mathrm{B}$ from water to $1 \mathrm{M} \mathrm{HCl}$, the slow transfer of the $\mathrm{C}_{5} \mathrm{Ph}(\mathrm{CN})_{4}$ anion was induced from phase A to phase $\mathrm{B}$ via the middle organic phase (entry 3). These results supported our hypothesis that $\mathrm{H}_{3} \mathrm{O}^{+}\left[\mathrm{C}_{5} \mathrm{Ph}(\mathrm{CN})_{4}\right]^{-}$(2),

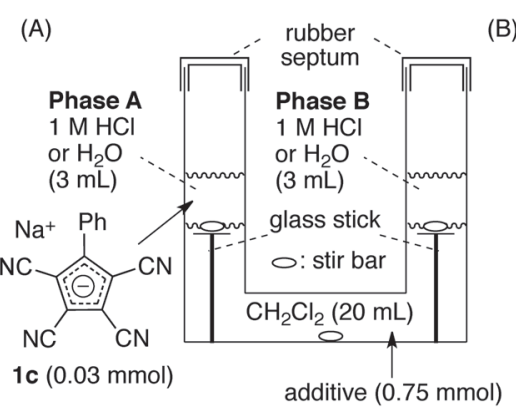

(B)

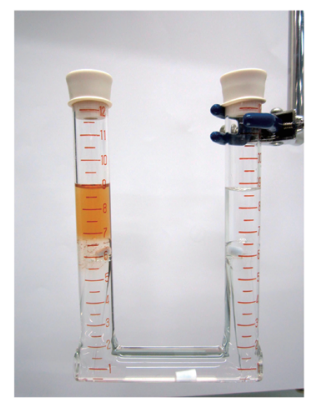

(C)

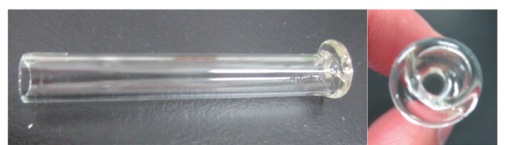

Fig. 4. Apparatus for the Measurement of the Phase-Transfer Rate

(A) Schematic; (B) Photograph of the apparatus; (C) Photograph of the glass stick. formed from $\mathrm{H}_{3} \mathrm{O}^{+} \mathrm{Cl}^{-}$and $\mathbf{1}$, is partitioned between the organic and aqueous phases. The addition of hydrophobic 3 and L-menthol accelerated the rate of transfer from phase A to phase $\mathrm{B}$ (entries 5, 6, respectively), ${ }^{27)}$ while with the addition of diethyl ether as an additive into the $\mathrm{CH}_{2} \mathrm{Cl}_{2}$ phase, the transfer rate of the $\mathrm{C}_{5} \mathrm{Ph}(\mathrm{CN})_{4}$ anion was slightly affected (entry 4). The acceleration effect of the former additives was attributed to the formation of a hydrophobic oxonium specie such as 4 shown in Fig. 2, which enhances the solublity of the $\mathrm{C}_{5} \mathrm{Ph}(\mathrm{CN})_{4}$ salt into the $\mathrm{CH}_{2} \mathrm{Cl}_{2}$ phase.

The hydronium cation carrier ability of $\mathbf{1}$ was also confirmed by $\mathrm{pH}$ measurements (Fig. 5). A similar experiment as shown in Table 2 was conducted using a U-tube apparatus charged with $1 \mathrm{M} \mathrm{HCl}$ for phase $\mathrm{A}$ and $\mathrm{H}_{2} \mathrm{O}$ for phase $\mathrm{B}$. The change of $\mathrm{pH}$ in phase $\mathrm{B}$ was measured at the indicated times. In the absence of 1c, the $\mathrm{pH}$ of phase B slowly decreased from 7.0 to 5.3 after $24 \mathrm{~h}(\mathbf{)})$. The addition of sodium salt $1 \mathrm{c}$ accelerated the decrease of $\mathrm{pH}$, attaining $\mathrm{pH} 2.8$ after $24 \mathrm{~h}(\boldsymbol{\Delta})$. The synergetic effect of an additive and salt $\mathbf{1 c}$ on the decrease of $\mathrm{pH}$ was also observed for the $\mathrm{C}_{5} \mathrm{Ph}(\mathrm{CN})_{4}$ anion transfer experiment summarized in Table 2 (entries 4-6). The addition of diethyl ether to the $\mathrm{CH}_{2} \mathrm{Cl}_{2}$ phase did not change the rate $(\diamond)$, while hydrophobic 3 or L-menthol significantly accelerated the $\mathrm{pH}$ decrease of phase $\mathrm{B}(\times$ and +$)$. When $\mathrm{NaBF}_{4}$ was employed instead of $\mathbf{1 c}$, the rate of $\mathrm{pH}$ decrease was much slower than when 1c was used $(\square)$, consistent with the result of the hydrolysis reactions shown in Table 1, entry 6.

In conclusion, we discovered that tetracyanocyclopen-

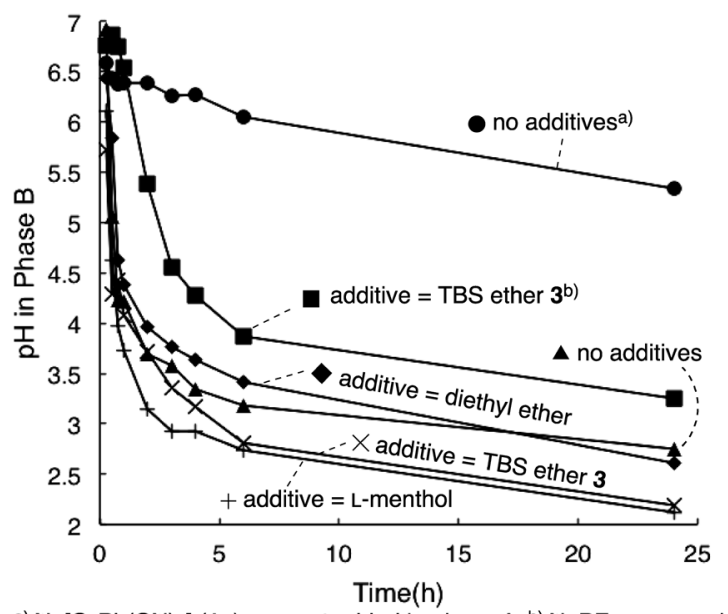

a) $\mathrm{Na}\left[\mathrm{C}_{5} \mathrm{Ph}(\mathrm{CN})_{4}\right]$ (1c) was not added in phase $\mathrm{A}$. b) $\mathrm{NaBF}_{4}$ was used instead of $1 \mathrm{C}$.

Fig. 5. Change of $\mathrm{pH}$ in Phase B When $1 \mathrm{M} \mathrm{HCl}$ and $\mathrm{H}_{2} \mathrm{O}$ Were Used for Phases A and B, Respectively

Table 2. Percentages of the Remaining $\mathrm{C}_{5} \mathrm{Ph}(\mathrm{CN})_{4}$ Anion 1c in Phase A and the Transferred $\mathrm{C}_{5} \mathrm{Ph}(\mathrm{CN})_{4}$ Anion to Phase $\mathrm{B}$

\begin{tabular}{|c|c|c|c|c|c|c|}
\hline \multirow{2}{*}{ Entry } & \multirow{2}{*}{ Phase A/Phase B } & \multirow{2}{*}{ Additive } & \multicolumn{4}{|c|}{ Phase A $(\%) /$ Phase B $\left.(\%)^{a}\right)$} \\
\hline & & & $2 \mathrm{~h}$ & $6 \mathrm{~h}$ & $24 \mathrm{~h}$ & $48 \mathrm{~h}$ \\
\hline 1 & $\mathrm{H}_{2} \mathrm{O} / \mathrm{H}_{2} \mathrm{O}$ & - & $101 / 0$ & $100 / 0$ & $102 / 0$ & - \\
\hline 2 & $\mathrm{H}_{2} \mathrm{O} / \mathrm{H}_{2} \mathrm{O}$ & TBS ether 3 & $105 / 0$ & $104 / 0$ & $104 / 0$ & - \\
\hline 3 & $1 \mathrm{M} \mathrm{HCl} / 1 \mathrm{M} \mathrm{HCl}$ & - & $88 / 2$ & $79 / 3$ & $81 / 3$ & $77 / 11$ \\
\hline 4 & $1 \mathrm{~m} \mathrm{HCl} / 1 \mathrm{M} \mathrm{HCl}$ & Diethyl ether & $93 / 1$ & $92 / 8$ & $76 / 15$ & $73 / 21$ \\
\hline 5 & $1 \mathrm{M} \mathrm{HCl} / 1 \mathrm{~m} \mathrm{HCl}$ & TBS ether $\mathbf{3}$ & $90 / 4$ & $68 / 16$ & $50 / 32$ & $41 / 36$ \\
\hline 6 & $1 \mathrm{~m} \mathrm{HCl} / 1 \mathrm{~m} \mathrm{HCl}$ & L-Menthol & $79 / 6$ & $65 / 13$ & $53 / 25$ & $43 / 28$ \\
\hline
\end{tabular}

a) Each percentage was calculated on the basis of the initial amount in phase A. 
tadienides $\mathbf{1}$ promote the hydrolysis of TBS ether $\mathbf{3}$ in a $\mathrm{CH}_{2} \mathrm{Cl}_{2}-1 \mathrm{M} \mathrm{HCl}$ biphasic solvent system via the formation of lipophilic hydronium salt $\mathbf{2}$. The capability of $\mathbf{2}$ as a phasetransfer catalyst was also demonstrated by experiments conducted using a triphasic system with a right-angled U-tube. Currently, more experiments for verifying the synthetic utility of catalyst $\mathbf{1}$ is underway in our laboratory.

\section{Experimental}

Hydrolysis of TBS Ether 3 in a Biphasic System Using Catalyst 1a (Table 1, Entry 4) To a solution of TBS ether $\mathbf{3}^{28)}(100 \mathrm{mg}, 0.37 \mathrm{mmol})$ in $\mathrm{CH}_{2} \mathrm{Cl}_{2}(1.0 \mathrm{~mL})$ was added $1 \mathrm{M}$ $\mathrm{HCl}(0.50 \mathrm{~mL}, 0.50 \mathrm{mmol})$ and tetracyanocyclopentadienide 1a $(7.4 \mathrm{mg}, 0.02 \mathrm{mmol})$ and the reaction mixture was stirred for $2 \mathrm{~h}$. The reaction was quenched with saturated aq $\mathrm{NaHCO}_{3}$ and the mixture was extracted with EtOAc. The extract was washed with brine, dried over $\mathrm{Na}_{2} \mathrm{SO}_{4}$, filtered, and concentrated under reduced pressure. Purification by flash chromatography (20\% EtOAc in $n$-hexane) afforded L-menthol (53 mg, 92\%). Further elution with EtOAc provided recovered 1a (6.4 mg, 86\% recovered).

L-Menthol. ${ }^{1} \mathrm{H}-\mathrm{NMR}\left(\mathrm{CDCl}_{3}, 500 \mathrm{MHz}\right) \delta: 3.40(1 \mathrm{H}, \mathrm{td}$, $J=10.4,4.4 \mathrm{~Hz}), 2.18(1 \mathrm{H}, \mathrm{sptd}, J=7.0,2.7 \mathrm{~Hz}), 1.96(1 \mathrm{H}, \mathrm{dtd}$, $J=12.1,3.9,2.1 \mathrm{~Hz}), 1.66(1 \mathrm{H}, \mathrm{dqd}, J=3.2,2.5 \mathrm{~Hz}), 1.61(1 \mathrm{H}$, dq, $J=12.9,3.2 \mathrm{~Hz}), 1.56(1 \mathrm{H}$, br s), $1.42(1 \mathrm{H}, \mathrm{tqt}, J=11.5,7.0$, $3.4 \mathrm{~Hz}), 1.11(1 \mathrm{H}$, ddt, $J=12.4,9.8,3.1 \mathrm{~Hz}), 1.01-0.81(3 \mathrm{H}, \mathrm{m})$, $0.93(3 \mathrm{H}, \mathrm{d}, J=7.0 \mathrm{~Hz}), 0.91(3 \mathrm{H}, \mathrm{d}, J=7.0 \mathrm{~Hz}), 0.81(3 \mathrm{H}, \mathrm{d}$, $J=7.0 \mathrm{~Hz})^{29)}$

Hydrolysis of Acetonide 5 in a Biphasic System Using Catalyst 1c (Eq. 1) To a solution of acetonide $\left.\mathbf{5}^{30}\right)(100 \mathrm{mg}$, $0.56 \mathrm{mmol})$ in $\mathrm{CH}_{2} \mathrm{Cl}_{2}(1.5 \mathrm{~mL})$ was added $1 \mathrm{M} \mathrm{HCl}(0.75 \mathrm{~mL})$ and catalyst $1 \mathrm{c}(7.4 \mathrm{mg}, 0.028 \mathrm{mmol})$, and the reaction mixture was stirred for $2 \mathrm{~h}$. The reaction was quenched with saturated aq $\mathrm{NaHCO}_{3}$ and the mixture was extracted with EtOAc. The extract was washed with brine, dried over $\mathrm{Na}_{2} \mathrm{SO}_{4}$, filtered, and concentrated under reduced pressure. Purification by flash chromatography (80\% EtOAc in $n$-hexane) afforded diol 6 (53 mg, 92\%). Further elution with EtOAc provided recovered 1c $(6.0 \mathrm{mg}, 81 \%$ recovered).

Diol 6. ${ }^{1} \mathrm{H}-\mathrm{NMR}\left(\mathrm{CDCl}_{3}, 500 \mathrm{MHz}\right) \delta$ : 7.36-7.26 (5H, m), $4.81(1 \mathrm{H}, \mathrm{dd}, J=8.1,3.4 \mathrm{~Hz}), 3.74(1 \mathrm{H}, \mathrm{dd}, J=11.3,3.4 \mathrm{~Hz}), 3.66$ $(1 \mathrm{H}, \mathrm{dd}, J=11.3,8.1 \mathrm{~Hz}), 2.88$ (1H, br s), 2.44 (1H, br s). ${ }^{29)}$

Acid-Catalyzed Rearrangement of cis-Stilbene Oxide (7) to Aldehyde 8 (Eq. 2) To a solution of cis-stilbene oxide (7) $(50.0 \mathrm{mg}, 0.25 \mathrm{mmol})$ in $\mathrm{CH}_{2} \mathrm{Cl}_{2}(1 \mathrm{~mL})$ was added $1 \mathrm{M} \mathrm{HCl}$ $(0.5 \mathrm{~mL})$ and catalyst $1 \mathrm{e}(2.9 \mathrm{mg}, 0.014 \mathrm{mmol})$, and the reaction mixture was stirred for $24 \mathrm{~h}$. The reaction was quenched with saturated aq $\mathrm{NaHCO}_{3}$ and the mixture was extracted with EtOAc. The extract was washed with brine, dried over $\mathrm{Na}_{2} \mathrm{SO}_{4}$, filtered, and concentrated under reduced pressure. Purification by flash chromatography $\left(10 \% \mathrm{Et}_{2} \mathrm{O}\right.$ in $n$-hexane) afforded diol 6 (28.2 mg, 58\%). Further elution with EtOAc provided recovered $1 \mathrm{e}(1.9 \mathrm{mg}, 66 \%$ recovered).

Aldehyde 8. ${ }^{1} \mathrm{H}-\mathrm{NMR}\left(\mathrm{CDCl}_{3}, 500 \mathrm{MHz}\right) \delta$ : $9.94(1 \mathrm{H}, \mathrm{d}$, $J=2.5 \mathrm{~Hz}), 7.40-7.34(4 \mathrm{H}, \mathrm{m}), 7.30(2 \mathrm{H}, \mathrm{tt}, J=7.3,1.5 \mathrm{~Hz})$, $7.24-7.20(4 \mathrm{H}, \mathrm{m}), 4.89(1 \mathrm{H}, \mathrm{d}, J=2.5 \mathrm{~Hz})^{29}{ }^{29}$

General Procedure for the NMR Experiment of the Hydrolysis of TBS Ether 3 in a Biphasic System (Fig. 3) An NMR tube was charged with a solution of TBS ether $\mathbf{3}$ $(30 \mathrm{mg}, 0.11 \mathrm{mmol})$ and benzene (internal standard, $10 \mu \mathrm{L})$ in $\mathrm{CD}_{2} \mathrm{Cl}_{2}(0.6 \mathrm{~mL})$. A solution of tetracyanocyclopentadienide $\mathbf{1}$
( $0.0055 \mathrm{mmol}, 0.05$ equiv) in $1 \mathrm{M} \mathrm{HCl}(0.3 \mathrm{~mL})$ was added, followed by vigorous manual shaking. The mixture was allowed to stand for the indicated time. The yields were calculated on the basis of the integration of the ${ }^{1} \mathrm{H}-\mathrm{NMR}$ signals of Lmenthol (0.74 ppm for methyl group) and benzene (7.37 ppm).

General Procedure of the U-Tube Experiment for the $\mathrm{C}_{5} \mathrm{Ph}(\mathrm{CN})_{4}$ Salt Solubility in $\mathrm{CH}_{2} \mathbf{C l}_{2}$ (Table 2) A rightangled U-tube equipped with two glass sticks and three magnetic stir bars (Fig. 4) was charged with a solution of an additive $(0.75 \mathrm{mmol})$ in $\mathrm{CH}_{2} \mathrm{Cl}_{2}(20 \mathrm{~mL})$. A solution of $1 \mathrm{c}$ ( $8 \mathrm{mg}, 0.03 \mathrm{mmol})$ in $1 \mathrm{M} \mathrm{HCl}$ or $\mathrm{H}_{2} \mathrm{O}(3 \mathrm{~mL})$ was added to one side of the U-tube (phase $\mathrm{A})$, and $1 \mathrm{M} \mathrm{HCl}$ or $\mathrm{H}_{2} \mathrm{O}(3 \mathrm{~mL})$ was added to the other side (phase $\mathrm{B}$ ), and the system was stirred at a rate of approx. $1000 \mathrm{rpm}$. The amount of the $\mathrm{C}_{5} \mathrm{Ph}(\mathrm{CN})_{4}$ anion was measured at the indicated time according to the following procedures. A $10 \mu \mathrm{L}$ sample was collected using a micropipette and diluted with a $0.025 \%(\mathrm{w} / \mathrm{v})$ phenol aqueous solution in a $5 \mathrm{~mL}$ volumetric flask. The resulting solution was analyzed by HPLC (Develosil C30-UG-5, 70\% MeOH/25 mM aqueous $\mathrm{Na}_{2} \mathrm{HPO}_{4}, 0.8 \mathrm{~mL} / \mathrm{min}, 254 \mathrm{~nm}, 5.7 \mathrm{~min}$ for phenol and $9.5 \mathrm{~min}$ for $1 \mathrm{c}$ ), and the percentages of the remaining $\mathrm{C}_{5} \mathrm{Ph}(\mathrm{CN})_{4}$ anion in phase $\mathrm{A}$ or the transferred $\mathrm{C}_{5} \mathrm{Ph}(\mathrm{CN})_{4}$ anion to phase $\mathrm{B}$ were calculated on the basis of the initial amount of $1 \mathbf{c}$ in phase A.

Acknowledgments This study was partially supported by a Grant-in-Aid for Scientific Research (C) (24590033), Grantin-Aid for Young Scientists (B) (26860018) from the Japan Society for the Promotion of Science (JSPS), and the Science Research Promotion Fund from the Promotion and Mutual Aid Corporation for Private Schools of Japan.

Conflict of Interest The authors declare no conflict of interest.

Supplementary Materials The online version of this article contains supplementary materials.

\section{References and Notes}

1) "Phase-Transfer Catalysis Mechanisms and Syntheses," ed. by Halpern M. E., ACS Symposium Series 659, American Chemical Society, Washington, DC, 1997.

2) Hashimoto T., Maruoka K., Chem. Rev., 107, 5656-5682 (2007).

3) "Asymmetric Phase Transfer Catalysis," ed. by Maruoka K., WileyVCH, Weinheim, 2008.

4) Kobayashi H., Sonoda T., Iwamoto H., Yoshimura M., Chem. Lett., 10, 579-580 (1981).

5) Iwamoto H., Kobayashi H., Murer P., Sonoda T., Zollinger H., Bull. Chem. Soc. Jpn., 66, 2590-2602 (1993).

6) Ichikawa J., Kobayashi H., Sonoda T., J. Synth. Org. Chem. Jpn., 46, 943-954 (1988).

7) Brak K., Jacobsen E. N., Angew. Chem. Int. Ed., 52, 534-561 (2013).

8) Mahlau M., List B., Angew. Chem. Int. Ed., 52, 518-533 (2013).

9) Hamilton G. L., Kanai T., Toste F. D., J. Am. Chem. Soc., 130, 14984-14986 (2008).

10) Rauniyar V., Lackner A. D., Hamilton G. L., Toste F. D., Science, 334, 1681-1684 (2011).

11) Phipps R. J., Hiramatsu K., Toste F. D., J. Am. Chem. Soc., 134, 8376-8379 (2012)

12) Honjo T., Phipps R. J., Rauniyar V., Toste F. D., Angew. Chem. Int. Ed., 51, 9684-9688 (2012).

13) Phipps R. J., Toste F. D., J. Am. Chem. Soc., 135, 1268-1271 (2013). 
14) Shunatona H. P., Früh N., Wang Y.-M., Rauniyar V., Toste F. D., Angew. Chem. Int. Ed., 52, 7724-7727 (2013).

15) Romanov-Michailidis F., Guénée L., Alexakis A., Angew. Chem. Int. Ed., 52, 9266-9270 (2013).

16) Xie W., Jiang G., Liu H., Hu J., Pan X., Zhang H., Wan X., Lai Y., Ma D., Angew. Chem. Int. Ed., 52, 12924-12927 (2013).

17) Liu H., Jiang G., Pan X., Wan X., Lai Y., Ma D., Xie W., Org. Lett., 16, 1908-1911 (2014)

18) Shen Z., Pan X., Lai Y., Hu J., Wan X., Li X., Zhang H., Xie W., Chem. Sci., 6, 6986-6990 (2015).

19) Webster O. W., J. Am. Chem. Soc., 87, 1820-1821 (1965).

20) Webster O. W., J. Am. Chem. Soc., 88, 4055-4060 (1966).

21) Simmons H. E., Vest R. D., Vladuchick S. A., Webster O. W., J. Org. Chem., 45, 5113-5121 (1980).

22) Webster O. W., J. Am. Chem. Soc., 88, 3046-3050 (1966).

23) Stoyanov E. S., Kim K.-C., Reed C. A., J. Am. Chem. Soc., 128, 8500-8508 (2006).

24) Sakai T., Seo S., Matsuoka J., Mori Y., J. Org. Chem., 78, 1097810985 (2013).

25) Octanol-water partition coefficient $(\log P)$ of $\mathrm{CHCl}_{3}(1.97)$ is higher than that of $\mathrm{CH}_{2} \mathrm{Cl}_{2}$ (1.25). Sangster J., J. Phys. Chem. Ref. Data, 18, 1111-1229 (1989).

26) The movie showing the experiment was attached as a supplementary material.

27) One referee pointed out that the total concentration of $1 \mathbf{c}$ in the combined aqueous phases A and B reduced to $c a$. $90 \%$ based on the initial amount of 1c in every entry. We consider that it is within the limits of experimental error because the total amount of $\mathbf{1 c}$ in the combined aqueous phases was with the same after 2 and $48 \mathrm{~h}$ for entries 3 and 4 . In entries 5 and $6,1 \mathrm{c}$ would be partially dissolved in the $\mathrm{CH}_{2} \mathrm{Cl}_{2}$ phase after $48 \mathrm{~h}$. A small amount of $1 \mathrm{c}$ was detected by ${ }^{1} \mathrm{H}-\mathrm{NMR}$ analysis of a $\mathrm{CH}_{2} \mathrm{Cl}_{2}$ extract from $1 \mathrm{c}$ solution in $1 \mathrm{M}$ $\mathrm{HCl}$, when 20 equiv of L-menthol was used as an additive for the extraction.

28) Matsubara H., Maegawa T., Kita Y., Yokoji T., Nomoto A., Org. Biomol. Chem., 12, 5442-5447 (2014).

29) Pouchert C. J., Behnke J., "The Aldrich Library of ${ }^{13} \mathrm{C}$ and ${ }^{1} \mathrm{H}$ FT NMR Spectra," Aldrich Chemical Company, Milwaukee, 1993.

30) Kliman L. T., Mlynarski S. N., Morken J. P., J. Am. Chem. Soc., 131, 13210-13211 (2009). 